\title{
The Effectiveness of Audit Guideline Using Directive Discourse for Control and Prevention of Methicillin Resistant Staphylococcus aureus Infection
}

\author{
Kusbaryanto $^{1}$, K. Kuntaman ${ }^{2}$, WJ. Pudjirahardjo ${ }^{3}$ \\ ${ }^{1}$ Department of Public Health Faculty of Medicine, University of Muhammadiyah Yogyakarta, Indonesia \\ ${ }^{2}$ Department Microbiology Faculty of Medicine, Airlangga University, Surabaya, Indonesia \\ ${ }^{3}$ Department of Administration Policy, Faculty of Public Health, Airlangga University, Suarabaya, Indonesia
}

\begin{tabular}{l}
\hline \hline Article Info \\
\hline Article history: \\
Received Nov 25, 2015 \\
Revised Jan 26, 2015 \\
Accepted Feb 27, 2016 \\
\hline
\end{tabular}

\section{Keyword:}

Audit Guideline

Directive discourse

MRSA

Situation awareness

\begin{abstract}
Methicillin Resistant Staphylococcus aureus (MRSA) infection is one of the major problems in the hospital, due to its increasing of prevalence. The aim of this study was to analyze the effectiveness of the Audit Guideline for control and prevention of MRSA infection, using directive discourse on nurses in hospitals. The Audit Guideline was focused on its effectiveness in improving the situation awareness of the nurses. This study was a quasiexperimental study using a pretest-posttest control group design. The population was ward nurses in a hospital. The samples were taken from four medical wards, two wards as the treatment group (25 nurses) and two wards as the control group (28 nurses). The two groups get the training of MRSA infection control and prevention. The training of the guideline of MRSA infection control and prevention using directive discourse was only applied in the treatment group. The analysis of the results of the situation awareness action was conducted, and the result of situation awareness action was improved from 0.8 response to 1.8 response $(p=0.014)$. This result was significantly difference because of the training using Audit Guideline for MRSA infections control and prevention with directive discourse become a positive reinforcement, the positive driven to stimulate behavior change of the nurses.
\end{abstract}

Copyright (C) 2016 Institute of Advanced Engineering and Science. All rights reserved.

\section{Corresponding Author:}

Kusbaryanto,

Public Health Department Medical and Health Faculty,

Muhammadiyah University of Yogyakarta.

Email: koesbary@yahoo.co.id

\section{INTRODUCTION}

Nosocomial infections are a big problem among hospitals world wide. The prevalence of nosocomial infections in developing countries is two to three times higher than in Europe or America. The incidence of nosocomial infections in intensive care units is higher than outside the intensive care unit [1].

One of the microbe that cause infections in hospitals is Methicillin Resistant Staphylococcus aureus (MRSA). The prevalence of MRSA is increasing, in 2004 the prevalence of Staphylococcus aureus colonization was $29 \%$ or 79.8 million people and the prevalence of MRSA was $1.5 \%$ or 4.1 million people from all over the United States population. In 2005 a total of 478.000 people were treated in hospitals in the United States due to Staphylococcus aureus infection, a total of 278.000 patients were related to MRSA [2]. To minimize the risk of infection in hospitals and other health care facilities, there needs to be improved the compliance of hand washing among health care workers, mainly nurse [3]. 
The prevalence of MRSA from nasal swab of students of the Faculty of Medicine, Airlangga University was $4.2 \%$ [4]. The study of Kuntaman et al (2014) about the prevalence rate of MRSA colonization among patients in dr. Soetomo Hospital of Surabaya was 8.1\% [5].

MRSA transmission is predicted common among health care workers, of both medical doctor and nurses. It was correlated to the behavior of health care workers, event though the facilities is also the other factor. The behavior should be improved to the better one, for suppressing the transmission of MRSA among patients. Improving situation awareness (SA) of nurses is one of the methods how to limit the transmission of the MRSA. Situation awareness is the awareness of a nurse against their surrounding situation that going on, in accordance of the prevention of MRSA transmission and infection. There are three levels of situation awareness, namely: perception, comprehension and projections [6]. One effort for increasing situation awareness is by using the Audit Guidelines that can be used and implemented by nurses. The Audit Guidelines of control and prevention of MRSA infections in hospital, was written in the form of directive discourse (DD) [7].

The research objective was to analys the effectiveness the Guideline of Audit in the control and prevention of MRSA infections with directive discourse in improving the situation awareness of the nurses in hospitals.

\section{RESEARCH METHOD}

The research was conducted in two phases, the first phase is to design and develop Audit Guidelines for the control and prevention of MRSA infections with the directive discourse (DD) method. Phase II was a quasi-experimental study using a pretest-posttest control group design [8].

The population of this research were ward nurses in $\mathrm{dr}$. Soetomo hospital of Surabaya. Samples were taken from 4 wards, 2 wards as treatment group and 2 wards as the control group. The numbers of samples 25 nurses for the treatment group and 28 nurses as a control group. All nurses in these four wards that meet to the inclusion criteria, were included in the study.

In both groups got the training on the control and prevention of MRSA infections, the training of Audit Guidelines with directive discourse was applied only for the treatment group. Data was collected from May 2013 until August 2013. Questionnaire about situation awareness of the control and prevention of MRSA infections and checklist of situation awareness were subjected for all nurses that included in the study. Each questionnaire was filled twice by included nurses, namely for pretest and posttest. The data was analysis by computer with level of significance 0.05 . The variables of perception, comprehension and projection were analyzed, between the treatment and the control group.

The study was agreed by Ethic committee of dr. Soetomo Hospital Surabaya. All subjects included in this study, signed a inform consent form before the starting the study.

\section{RESULTS AND ANALYSIS}

The distribution of age and length of work, and education were in Table 1 and Table 2. Of the 2 groups in the study subjects were then analysed their characteristics based on age, length of employment and education. Age, average of 37.2 years, standard deviation (SD) of 8.5 and a length of work, average of 12.2 years, SD 9.0. These data showed were homogenusly distribution (Kolmogorof-Smirnov) one sample test, $\mathrm{p}=$ 0.387 for age, and 0.212 for length of work.

Table 1. Results of research subject characteristics analysis based on age and length of employment variable in dr. Soetomo hospital in the year of 2014

\begin{tabular}{cccccccc}
\hline \multirow{2}{*}{ Variable } & \multicolumn{3}{c}{ Control Group } & \multicolumn{4}{c}{ Treatment Group } \\
\cline { 2 - 7 } & $\mathrm{n}$ & Mean & SD & $\mathrm{n}$ & Mean & SD & $0.387^{*}$ \\
\hline Age (year) & 28 & 40.0 & 8.5 & 25 & 37.2 & 8.5 & 0.3 \\
Length of Employment (year) & 28 & 7.2 & 13.0 & 25 & 12.2 & 9.0 & $0.312^{*}$ \\
\hline
\end{tabular}

*Not significant $(\mathrm{p}>0.05)$

The data of education was homogenous (Kolmogorof-Smirnov test, $\mathrm{p}=0.23$ ). 
Table 2. Results of research subject characteristic analysis of education variable in dr. Soetomo hospital in the year of 2014

\begin{tabular}{|c|c|c|c|c|}
\hline & & Control Group & Treatment Group & Total \\
\hline & High School n (\%) & $2(7.1 \%)$ & $0(0 \%)$ & $2(3.8 \%)$ \\
\hline \multirow[t]{2}{*}{ Education } & D 3 n (\%) & 20 (71.4\%) & 17 (68.0\%) & 37 (69.8\%) \\
\hline & D 4/S1 n (\%) & $6(21.4 \%)$ & $8(32.0 \%)$ & 14 (26.4\%) \\
\hline $\begin{array}{l}\text { Total n (\%) } \\
\text { P }\end{array}$ & & $28(100 \%)$ & $\begin{array}{l}25(100 \%) \\
0.230 *\end{array}$ & $53(100 \%)$ \\
\hline
\end{tabular}

The results measurement of the perception of situation awareness (Table 4) in the treatment group, mean 47.8 dan SD 12.2 and in the control group, mean 47.4 and SD 14. This data homogenously distribution (Kolmogorof-Smirnov test, $\mathrm{p}=0.091$ ).

Table 3. Differences of Perception between Control Group and Treatment Group before and after Treatment

\begin{tabular}{|c|c|c|c|c|c|c|c|}
\hline \multirow{2}{*}{ Variable } & \multicolumn{3}{|c|}{ Control Group } & \multicolumn{3}{|c|}{ Treatment Group } & \multirow[b]{2}{*}{$\mathrm{p}$} \\
\hline & $\mathrm{n}$ & Mean & SD & $\mathrm{n}$ & Mean & SD & \\
\hline Perception before treatment & 28 & 45.1 & 11.3 & 25 & 41.36 & 11.00 & $0.146^{*}$ \\
\hline Perception after treatment & 28 & 47.4 & 14.3 & 25 & 49.93 & 12.2 & $0.908^{*}$ \\
\hline $\mathrm{p}$ & & $0.155^{*}$ & & & $0.001^{* *}$ & & \\
\hline
\end{tabular}

*Not significant $(\mathrm{p}>0.05),{ }^{*}$ Significant $(\mathrm{p}<0.05)$, range of value $15-75$

The comprehension measurement results on MRSA infections prevention in the treatment group and the control group in Table 5. There was not significantly difference between treatment and control group (Mann-Whitney test, $\mathrm{p}=0.06$ )

Table 4. Differences of Comprehension in Control Group and Treatment Group before and after Treatment

\begin{tabular}{lccccccc}
\hline \multirow{2}{*}{ Variable } & \multicolumn{3}{c}{ Control Group } & \multicolumn{3}{c}{ Treatment Group } \\
\cline { 2 - 7 } & $\mathrm{n}$ & Mean & SD & $\mathrm{n}$ & Mean & SD & p \\
\hline Perception before treatment & 28 & 49.5 & 11.8 & 25 & 45.9 & 11.6 & $0.180^{*}$ \\
Perception after treatment & 28 & 52.7 & 15.6 & 25 & 48.1 & 13.2 & $0.085^{*}$ \\
$\mathrm{p}$ & & $0.028^{* *}$ & & & $0.175^{*}$ & & \\
\hline
\end{tabular}

*Not significant ( $>0.05)$, **Significant $(\mathrm{p}<0.05)$, range of value $15-75$

To the projection measurement results for MRSA infections prevention after treatment in the treatment group and in the control group, KS test was conducted. To the results, non-parametric test was performed using Mann-Whitney test and the result obtained was $\mathrm{p}=0.081$. This result was not significant, so that there was no difference the projection after treatment in the treatment group and the control group.

Table 5. Differences of Projection between Control Group and Treatment Group before and after treatment

\begin{tabular}{|c|c|c|c|c|c|c|c|}
\hline \multirow{2}{*}{ Variable } & \multicolumn{3}{|c|}{ Control Group } & \multicolumn{3}{|c|}{ Treatment Group } & \multirow{2}{*}{$\mathrm{p}$} \\
\hline & $\mathrm{n}$ & Mean & $\mathrm{SD}$ & $\mathrm{n}$ & Mean & SD & \\
\hline Perception before treatment & 28 & 50.7 & 12.5 & 25 & 46.4 & 12.9 & $0.193^{*}$ \\
\hline Perception after treatment & 28 & 55.8 & 14.2 & 25 & 51.7 & 10.9 & $0.105^{*}$ \\
\hline $\mathrm{p}$ & & $0.001 * *$ & & & $0.001^{* *}$ & & \\
\hline
\end{tabular}

To the results of the measurement of the situation awareness action for MRSA infections prevention after treatment in the treatment group and in the control group, Regression test was conducted. This test was done because test results before the treatment showed that there were differences between the treatment group and the control group. The result of Regression test was $p=0.014$, so that there were differences in situation awareness measurement practice after the treatment in both groups. 
Table 6. Differences of Situation Awareness Action between Control Group and Treatment Group before and after Treatment

\begin{tabular}{|c|c|c|c|c|c|c|c|}
\hline \multirow{2}{*}{ Variable } & \multicolumn{3}{|c|}{ Control Group } & \multicolumn{3}{|c|}{ Treatment Group } & \multirow[b]{2}{*}{$\mathrm{p}$} \\
\hline & $\mathrm{n}$ & Mean & SD & $\mathrm{n}$ & Mean & SD & \\
\hline Situation awarness action before treatment & 28 & 1.0 & 0.57 & 25 & 1.4 & 0.8 & $0.018^{*}$ \\
\hline Situation awareness action after treatment & 28 & 1.25 & 0.75 & 25 & 1.8 & 0.5 & $0.014^{*}$ \\
\hline $\mathrm{p}$ & & $0.157 *$ & & & $0.068 *$ & & \\
\hline
\end{tabular}

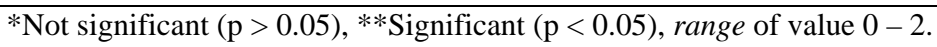

\subsection{Discussion}

Statistical analysis showed that differences in perception, comprehension, and projection after treatment were not significant. This indicates that treatment does not change perception, comprehension, and projection of situation awareness research subjects. There are several possible causes, among others: first, the complexity of the Audit Guidelines of control and prevention of MRSA infections and the instrument of intervention in the form of questionares situation awareness [9]. This is in accordance with the Audit Guidelines for assessment by a nurse for the lowest value with low average complexity compared to other assessment results, even though the overall average is good. Complaints for complexity also arise when they read the questionnaire of awareness of situation; the complexity was then ultimately affecting the understanding of the content of the problems and affects to posttest results, which was less satisfactory. Second, it is already good considering the understanding about the control and prevention of infection.

From the results of statistical analysis showed that differences in situation awareness action against MRSA infections after treatment in the control group and the treatment group obtained significant results. From these results it can be concluded that the treatment is effective in changing the situation awareness actions. Changes to the situation awareness action were caused by training of audit guidelines, the training becomes positive reinforcement and it becomes a stimulus to the improvement of situation awareness actions [10]. Changes in this situation awareness action are not accompanied by changes in the perception, comprehension and projection of situation awareness, that this change is predicted not to last long [11].

\section{CONCLUSION}

From the above discussion it can be concluded that the Audit Guidelines of MRSA infection prevention with directive discourse has not been clearly demonstrating its effectiveness for improving the perception, comprehension and projection of situation awareness, but has shown to be effective in improving situation awareness action

\section{REFERENCES}

[1] Naidu, K., Nabose, I., Ram, S., Viney, K., Graham, SM., Bissell, KA., "Descriptive Study of Nosocomial Infections in an Adult Intensive Care Unit in Fiji: 2011-12”, Journal of Tropical Medicine, Article ID 545160, 2014.

[2] CDC, “MRSA Infections”, 2011. Accessed June 17, 2012 from http://www.cdc.gov/mrsa/library/posters.html.

[3] Ministry of Health, "Pedoman Pencegahan dan Pengendalian Infeksi di Rumah sakit dan Fasilitas Kesehatan lainnya”, Depkes RI, pp. 3-1, 2008.

[4] Sa'diyah, N., Koendhori, EB., Kusumaningrum, D., "MRSA-carrier Detection in Semester-1 Students of Medical Doctor Program Faculty of Medicine Airlangga University Surabaya class 2009”, Folia Medika Indonesiana, vol. 48, pp. 126-130, 2012.

[5] Kuntaman, Hadi, U., Setiawan, F., Koendori, EB., Rusli, M., Santosaningsih, D., Severin, J., Verbrugh, HA., "Prevalence rate of Methicillin Resistant Staphylococcus aureus Flora from Nose and Troat of patients on admission in Medical and Surgical Wards, dr. Soetomo Hospital Surabaya”, Non publish, 2015.

[6] Endsley, MR., "Theoritical Underpinnings of Situation Awareness: a Critical Review in Endsley, MR., Garland, DJ., "Situation Awareness Analysis and Measurement”, Mahwah, NJ, Lawrence Erlbaum Associates, pp. 1-20, 2000.

[7] Kompaore, AEG., "Discourse Analysis of Directive Texts: The Case of Biblical Law", Associated Mennonite Biblical Seminary Elkhart, Indiana, USA, pp. 15-18, 2004.

[8] Polit, DF., Hungler, BP., "Nursing Research Principles and Methods”, Lippincott Philadelphia New York Baltimore, 6 edition, pp. 188, 1999.

[9] Rogers, EM., “Diffusion of Innovations”, The Free Press, New York, pp. 207-251, 1995.

[10] Woolkfolk, A., “Education Psycology Active Learning”, Pustaka pelajar, pp. 307-309, 2009.

[11] Mubarak, WI., Chayatin, N., Rozikin, K., "Promosi Kesehatan Sebuah Pengantar Proses Belajar Mengajar dalam Pendidikan”, Graha Ilmu, first edition, pp. 28-34, 2007. 


\section{BIOGRAPHIES OF AUTHORS}

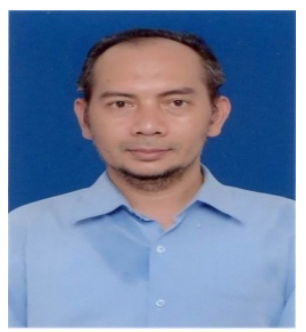

Dr.dr. Kusbaryanto, MKes. He is staff and lecturer in Department of Public Health Faculty of Medicine and Health Muhammadiyah University of Yogyakarta, Yogyakarta, Indonesia.

The research mainly in the context of public health control and prevention of infection desease The present position are member of health research centre and coordinator of human developmentFaculty of medicine and health Muhammadiyah University of Yogyakarta

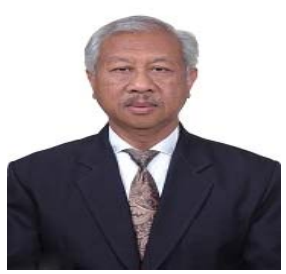

Prof. Kuntaman, MD., PhD., Clinical Microbiologist. He is staff and lecturer in Department of Microbiology Faculty of Medicine Airlangga University, Surabaya, Indonesia. Majoring in bacteriology. The research mainly in the context of bacterial resistance, such as Extended spectrum betalactamases produing bacteria, Carbapenemase producing bacteria, Methicillin Resistant Staphylococcus aureus, Hospital infection. The present positions are National advicer in National Program for Containment of antimicrobial resistance, Ministry of Health; Vice Dean Faculty of Medicine Airlangga University; Chairman of The College of Indonesian Society for Clinical Microbiology.

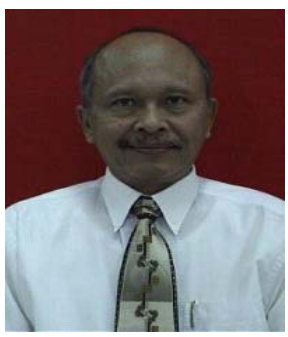

dr.Widodo J Pudjirahardjo, MPH, MSPH, Ph.D. He is staff and lecturer in Department administration and health policy of Faculty of Public health Airlangga University, Surabaya, Indonesia. The research mainly in the context administration and health policy. He is the consultan of hospital management. 